\title{
The Estimation of Biomass in Rhizophora apiculata and Rhizophora mucronata in Tuamese Village, North Central Timor Regency, East Nusa Tenggara Province
}

\author{
Ludgardis Ledheng ${ }^{1, *}$, Yolanda Getrudis Naisumu ${ }^{2}$, Remigius Binsasi ${ }^{2}$ \\ ${ }^{1}$ Study Program of Biology Education, Faculty of Education Sciences, Universitas Timor. Jl. El Tari Km. 9, Kefamenanu, 85613, \\ Nusa Tenggara Timur, Indonesia \\ ${ }^{2}$ Study Program of Biology, Faculty of Agriculture, Universitas Timor. Jl. El Tari Km. 9, Kefamenanu, 85613, Nusa Tenggara \\ Timur, Indonesia \\ * Corresponding Author. E-mail address: ludgardisledheng12@gmail.com
}

\section{ARTICLE HISTORY:}

Received: 4 June 2021

Peer review completed: 7 November 2021

Received in revised form: 15 November 2021

Accepted: 6 December 2021

\section{KEYWORDS:}

Biomass

Carbon uptake

Rhizophora apiculata

Rhizophora mucronata

C 2022 The Author(s). Published by Department of Forestry, Faculty of Agriculture, University of Lampung in collaboration with Indonesia Network for Agroforestry Education (INAFE) This is an open access article under the CC BY-NC license:

https://creativecommons.org/licenses/by$\mathrm{nc} / 4.0 /$

\begin{abstract}
Mangrove forest in North Central Timor Regency is dominated by Rhizophora sp. The highest number was found in Tuamese Village, namely Rhizophora apiculata and Rhizophora mucronata. The biomass productivity in mangrove forests varies according to age, dominant species, and locality. It shows differences in carbon uptake and storage at the level, type, and place of growth. This study aimed to analyze the carbon content and carbon uptake of $R$. apiculata and $R$. mucronata at the stake level to the tree level in two plots with the size of $2,000 \mathrm{~m}^{2}$ each. The method used was allometric equations, while the power discrimination test used an independent sample t-test. The result showed that $R$. apiculata and $R$. mucronata had the same potential in producing biomass and necromass as well as in storing and absorbing carbon. The total biomass was 77.21 $\mathrm{Mg} / \mathrm{ha}$, which can absorb and store carbon, respectively, $141.68 \mathrm{Mg} / \mathrm{ha}$ and $36.61 \mathrm{Mg} / \mathrm{ha}$. This research data provides an overview of the potential of biomass in meeting carbon trading standards as an effort to succeed in mangrove conservation in Tuamese Village.
\end{abstract}

\section{Introduction}

The total mangrove forests in North Central Timor Regency, East Nusa Tenggara Province, is 298.26 ha (Ledheng et al. 2012). Rhizophora sp. dominated this forest stands at the sapling and seedling strata with the important value index (IVI) of $106.93 \%$ and $50.02 \%$. In comparison, Bruguiera sp. dominated the tree and the pole level with the IVI of $79.49 \%$ and $99.88 \%$, respectively (Ledheng et al. 2012). The intense pressure on the tree strata every year has caused the growth and the development of Bruguiera sp. to be threatened (Ledheng et al. 2012). A study by Ledheng et al. (2020) in North Central Timor Regency found four mangrove species, namely Rhizophora apiculata, Rhizophora mucronata, Sonneratia alba, and Avicennia marina. The results indicated that there had been a change in the dominance and the extinction of Bruguiera sp. The damage and the disruption to the growth strata are the obstacles to the tree regeneration process where young trees will replace the mature trees (Heriyanto and Subiandono 2012). Ledheng et al. (2020) found $R$. apiculata and R. mucronata at the sapling to tree strata in Tuamese village, North Central Timor Regency. These species were the dominant Rhizophora's genus in 
the mangrove forest area because they have the characteristics of the hypocotyl that has germinated while still in the trees. Therefore, these species are relatively easier to breed for revegetation in the coastal areas (Irawan et al. 2013).

Concerning the mitigation of global warming, the mangrove forest in Tuamese Village has a role in reducing the release of carbon into the air. Therefore, it is vital to suppress the release of carbon as low as possible and optimize the amount of carbon uptake by the forest, where the carbon absorbed could be stored in the stems, leaves, roots, and the most significant carbon store is in the stems (Nurruhwati et al. 2018). However, the productivity of mangrove forest biomass varies according to age, dominant species, and location (Qiu et al. 2011). In other words, the stand carbon potential is different at the growth level, species, and the place of growth. For example, $R$. mucronata generally grows in the group on tidal river embankments and in the estuary so that it grows more towards the sea. Meanwhile, $R$. apiculata lives side by side with $R$. mucronata but grows more towards the mainland (Jumiati 2008). Therefore, this study aimed to determine the carbon content and the $\mathrm{CO}_{2}$ uptake of $R$. apiculata and $R$. mucronata stands in Tuamese Village.

\section{Materials and Methods}

\subsection{Research Location}

The research was carried out from October 2020 - January 2021 in the mangrove forest of Tuamese Village, Biboki Anleu District, North Central Timor Regency, East Nusa Tenggara Province. The research samples were taken at two location points (Fig. 1). The first location is dominated by $R$. apiculata (9³'45.62" S; $124^{\circ} 42^{\prime} 38.05^{\prime}$ " E), while the second location is dominated by R. Mucronata (9॰3’34.38' S; $124^{\circ} 42^{\prime} 58.66^{\prime \prime}$ E).

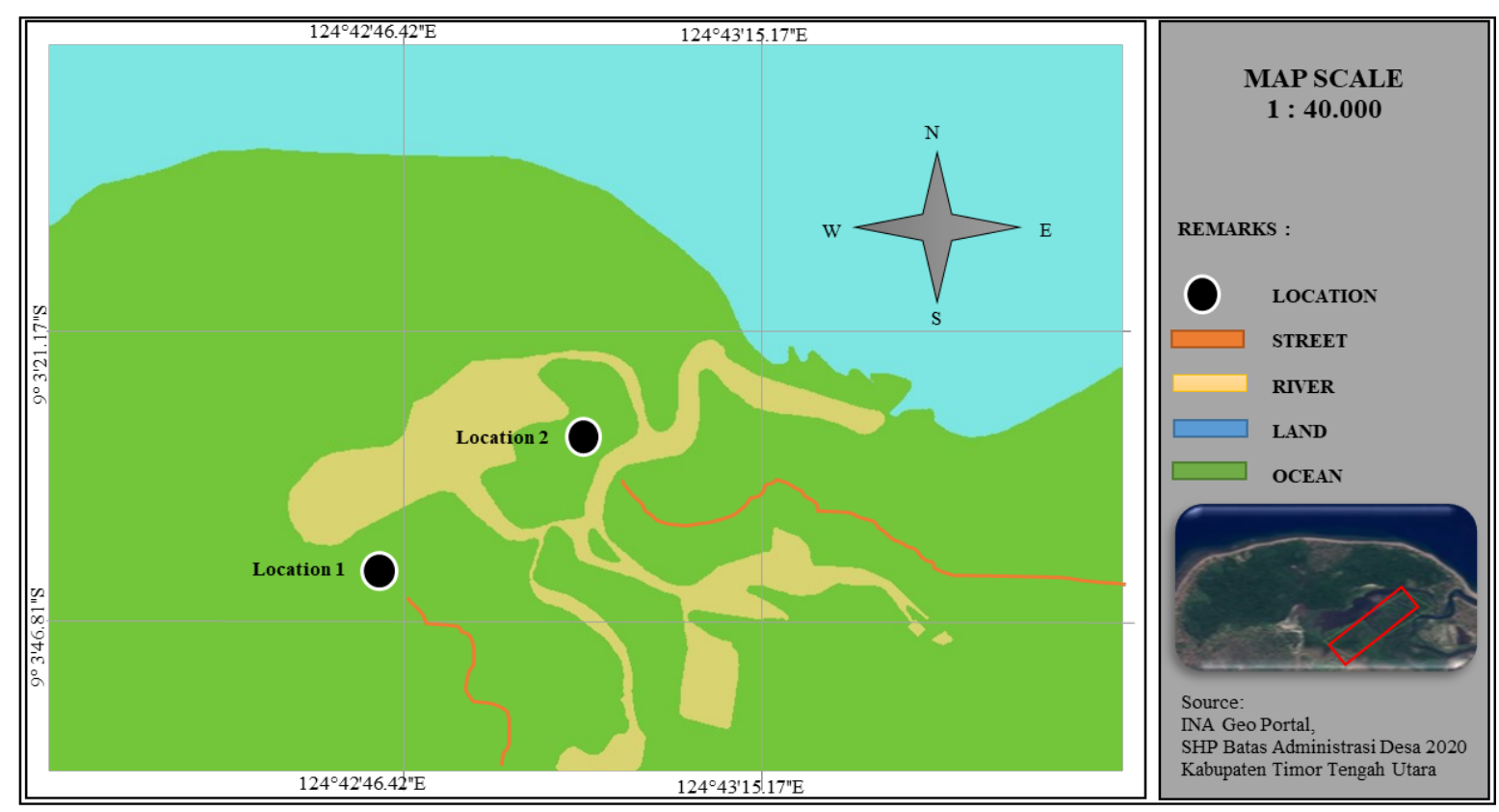

Fig 1. Research location.

\subsection{Materials}

The tools and materials used were roll meters $(50 \mathrm{~m})$, plastic ropes, the stake of diameter at breast height $(1.3 \mathrm{~m})$, machetes, observation forms, and the 30 observation specimens for each tree species. 


\subsection{Data Collection}

Two large plots of 2,000 $\mathrm{m}^{2}$ consisting of one sub-plot measuring $200 \mathrm{~m}^{2}$ were developed (Fig. 2). The observation of biomass and necromass was carried out on the trees with diameters $>$ $5 \mathrm{~cm}$ to $30 \mathrm{~cm}$. In addition, the trunk diameter was measured at a breast height of $1.3 \mathrm{~m}$ (Fig. 3).

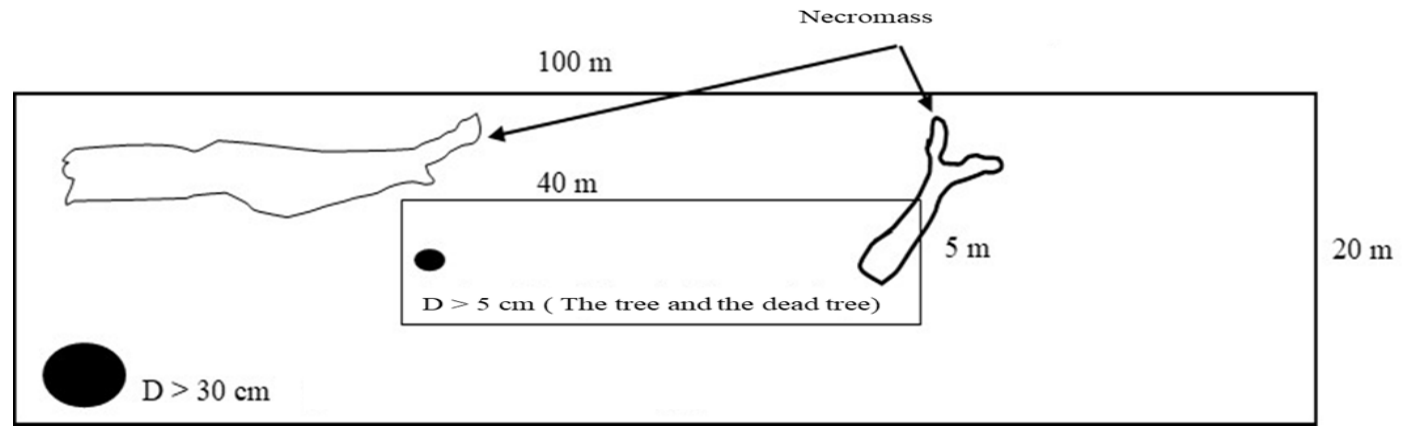

Fig. 2. Plot shape and size for each diameter group.

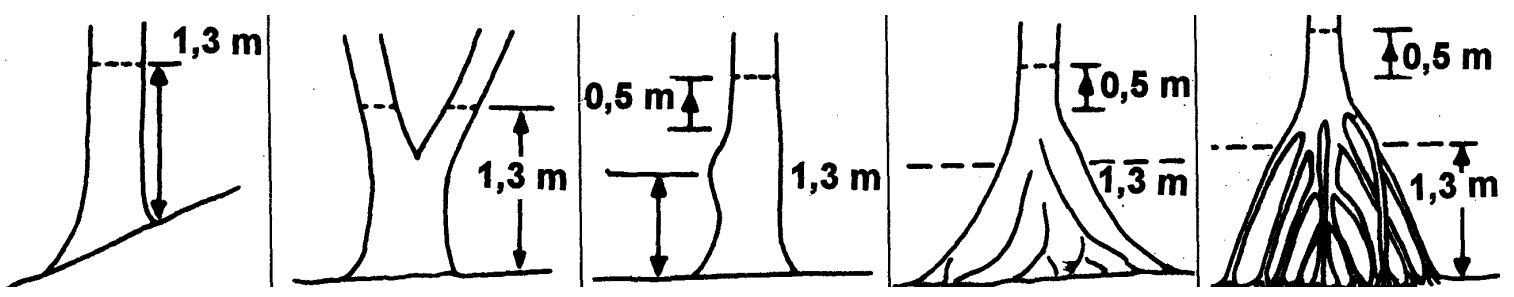

Fig. 3. The position of diameter measurement (Weyerhaeuser and Tennigkeit 2000).

\subsection{Data Analysis}

\subsubsection{Biomass}

The biomass calculation in $R$. apiculata used equation 1 (Amira 2008), while in $R$. mucronata used equation 2 (Dharmawan 2010).

$$
\begin{aligned}
& B=0.043 \times D^{2.63} \\
& B=0.1466 \times D^{23136}
\end{aligned}
$$

where $B$ is biomass $(\mathrm{Mg} / \mathrm{ha})$ and $D$ is diameter at breast height $(\mathrm{cm})$.

\subsubsection{Necromass}

The calculation of necromass used the allometric formula developed by Hairiah and Rahayu (2007).

$$
N=\pi x \rho x\left(\frac{d b h}{40}\right)^{2} x t x f
$$

where $N$ is necromass $(\mathrm{kg}), t$ is tree height $(\mathrm{cm}), f$ is the constant value $(0.6)$.

\subsubsection{Carbon content}

The carbon content is calculated based on the biomass data. The carbon content was calculated using equation 4 (Dharmawan 2010).

$$
C=B \times 0.5
$$


where $C$ is the carbon content $(\mathrm{Mg} / \mathrm{ha}), B$ is biomass $(\mathrm{Mg} / \mathrm{ha})$, and 0.5 is the conversion factor value.

\subsubsection{Carbon dioxide uptake}

The carbon dioxide $\left(\mathrm{CO}_{2}\right)$ uptake $(\mathrm{Mg} / \mathrm{ha})$ was calculated using the formula of Dharmawan (2010).

$$
\mathrm{CO}_{2} \text { Uptake }=3.7 \times \mathrm{C}
$$

where 3.7 is a constant and $C$ is the carbon content $(\mathrm{Mg} / \mathrm{ha})$.

After acquiring the data of biomass, carbon content, and $\mathrm{CO}_{2}$ uptake, the t-test was conducted to determine the differences between $R$. apiculata and $R$. mucronata.

\section{Results and Discussion}

\subsection{Biomass, Carbon Content, and $\mathrm{CO}_{2}$ Uptake}

Table 1 shows that the biomass of $R$. apiculata was $39.42 \mathrm{Mg} / \mathrm{ha}$ and could store and absorb the carbon of $19.71 \mathrm{Mg} / \mathrm{ha}$ and $72.33 \mathrm{Mg} / \mathrm{ha}$, respectively. The value of $\mathrm{CO}_{2}$ uptake of $R$. apiculata was equal to $482.2 \mathrm{~kg} /$ tree, which is higher than the $\mathrm{CO}_{2}$ uptake of $R$. apiculata in Gampong Jawa and Lambaro Banda Aceh of $4.03 \mathrm{~kg} /$ tree (Dewiyanti et al. 2019). The higher $\mathrm{CO}_{2}$ uptake of $R$. apiculata in Tuamese Village was due to higher tree diameter than in Gampong Jawa and Lambaro Banda Aceh. The biomass content of R. mucronata was $37.79 \mathrm{Mg} / \mathrm{ha}$, which could store and absorb carbon of $18.90 \mathrm{Mg} / \mathrm{ha}$ and $69.35 \mathrm{Mg} / \mathrm{ha}$, respectively (Table 1). The $\mathrm{CO}_{2}$ uptake of $R$. mucronata in Tuamese Village was higher than in Oebelo, Kupang Regency of $48.75 \mathrm{Mg} / \mathrm{ha}$ (Manafe et al. 2016), and in Ciasem Purwakarta of 0.14 Mg/ha (Dharmawan 2010).

Table 1. Biomass, carbon content, and $\mathrm{CO}_{2}$ uptake

\begin{tabular}{lccc}
\hline \multicolumn{1}{c}{ Species } & Biomass $\mathbf{( M g} / \mathbf{h a})$ & Carbon content $\mathbf{( M g} / \mathbf{h a})$ & $\mathbf{C O}_{2}$ uptake $\left.\mathbf{( M g} / \mathbf{h a}\right)$ \\
\hline R. apiculata & $39.42 \mathrm{a}$ & $19.71 \mathrm{a}$ & $72.33 \mathrm{a}$ \\
R. mucronata & $37.79 \mathrm{a}$ & $18.90 \mathrm{a}$ & $69.35 \mathrm{a}$ \\
Total & 38.61 & 19.30 & 70.84 \\
\hline
\end{tabular}

Note: Numbers followed by the same notation showed no significant difference according to the t-test at the significant level $\alpha=0.05$.

Rahim et al. (2018) reported that the $\mathrm{CO}_{2}$ uptake of $R$. mucronata reached $31.97 \mathrm{Mg} / \mathrm{ha}$, higher than the $\mathrm{CO}_{2}$ uptake of Ceriops tagal at $0.48 \mathrm{Mg} / \mathrm{ha}$ in the two tree samples. On the other hand, the $\mathrm{CO}_{2}$ uptake of $C$. tagal was lower than that of $A$. marina, which amounted to one tree. Therefore, the number of individual plants does not always have a high $\mathrm{CO}_{2}$ uptake but is also affected by tree diameter. Heriyanto and Subiandono (2012) stated that the absorbed carbon is converted into energy for photosynthesis and enters the plant structure into cellulose which makes up the stem organs. Plants then use the tree growth through photosynthesis to grow horizontally and vertically. Therefore, the larger the diameter, the bigger the biomass storage resulting from $\mathrm{CO}_{2}$ conversion and the increase in $\mathrm{CO}_{2}$ absorbed by plants. However, the results of the t-test on biomass, carbon content, and $\mathrm{CO}_{2}$ uptake did not show differences (Table 2). 
Table 2. T-test analysis between $R$. apiculata and $R$. mucronata

\begin{tabular}{lc}
\hline Parameter & Sig. (2-tailed). \\
\hline Biomass & 0.58 \\
Carbon content & 0.64 \\
$\mathrm{CO}_{2}$ uptake & 0.59 \\
\hline
\end{tabular}

The ability of the mangrove forest to absorb and store carbon is highly dependent on the soil and climatic conditions. According to Heriyanto and Subiandono (2012), biomass production in mangrove forests is strongly affected by soil fertility. Therefore, $R$. apiculata and $R$. mucronata growth are influenced by the condition of the base substrate as a nutrient provider for plants. These species are generally found in slightly sandy loamy sediments. The environmental conditions of $R$. apiculata and $R$. mucronata in Tuamese Village is presented in Table 3.

Table 3. Environmental parameters

\begin{tabular}{lcc}
\hline \multirow{2}{*}{ Parameters } & \multicolumn{2}{c}{ Station } \\
\cline { 2 - 3 } & R. mucronata & R. apiculata \\
\hline Temperature (C) & 29.22 & 28.87 \\
pH & 7.60 & 7.50 \\
Salinity (\%) & 30 & 30 \\
pH sediment & 8.50 & 8.55 \\
C-Organic (\%) & 3.39 & 4.04 \\
N Total (\%) & 0.07 & 0.03 \\
P Availability (ppm) & 28.78 & 44.47 \\
K Availability (ppm) & 671.42 & 624.77 \\
Texture: Sand & 56.39 & 47.24 \\
$\quad$ Dust & 33.63 & 39.33 \\
$\quad$ Clay & 25.42 & 29.87 \\
The Class of Sediment Texture & Sandy Clay & Sandy Clay \\
\hline
\end{tabular}

Source: Ledheng et al. (2012).

$R$. apiculata and $R$. mucronata in Tuamese Village generally have similar physical and chemical characteristics such as temperature, $\mathrm{pH}$, salinity, sediment $\mathrm{pH}$, and substrate characteristics to adapt well. Mustika et al. (2014) also stated that the adaptability and the tolerance to the environment greatly influenced the growth of $R$. apiculata in Muara Village, Teluk Naga District, Tangerang, Banten.

According to the Regional Government of North Central Timor (2016), the location of mangroves in Tuamese Village is a conservation area. Therefore, the planting pattern followed the development of conservation forests. Based on several factors, namely the sediment and the ecological suitability, the planting time and spacing in the conservation area also affect the growth of the two species. Dewiyanti et al. (2019) reported similar results, stating that $\mathrm{CO}_{2}$ uptake of $R$. apiculata and $R$. mucronata in the Gampong Java and Lambaro mangrove areas in Banda Aceh was influenced by the planting time and spacing for each species. Plant spacing is essential in providing optimal growth space for mangrove growth because it affects light, nutrients, water, and $\mathrm{CO}_{2}$. 
The distribution of diameter sizes at the two observation locations is not much different. The average diameter of $R$. apiculata was $27.20 \mathrm{~cm}$, while that of $R$. mucronata was $24.63 \mathrm{~cm}$. The average diameter observed was higher than the observations of $R$. apiculata and R. mucronata in Tarjun Village, South Kalimantan (Ariani et al. 2016), which were $21 \mathrm{~cm}$ and $19 \mathrm{~cm}$, respectively. The distribution of diameters is presented in Fig. 4.

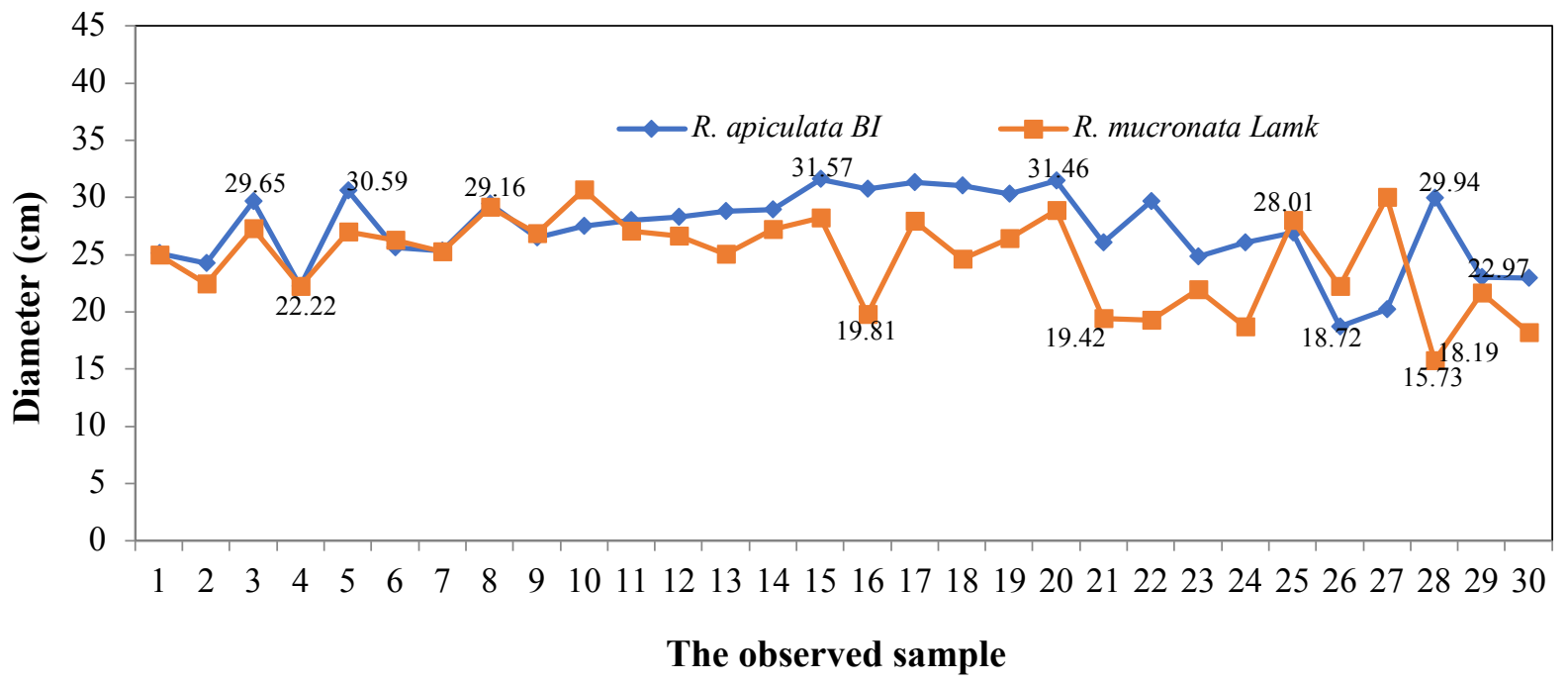

Fig. 4. The diameter size of $R$. apiculata and $R$. mucronata.

The result of the t-test did not show any difference in the diameter size between $R$. apiculata and $R$. mucronata. The similarity in diameter growth might be due to the similarity of the basic substrate in the observation area, which affects the supply of plant nutrients. It was reported that the increase in the average diameter of $R$. apiculata was strongly influenced by soil organic matter content (Herpinawati et al. 2010). The relationship between the number of individuals and the observed diameter class is presented in Fig. 5 and Fig. 6, respectively.

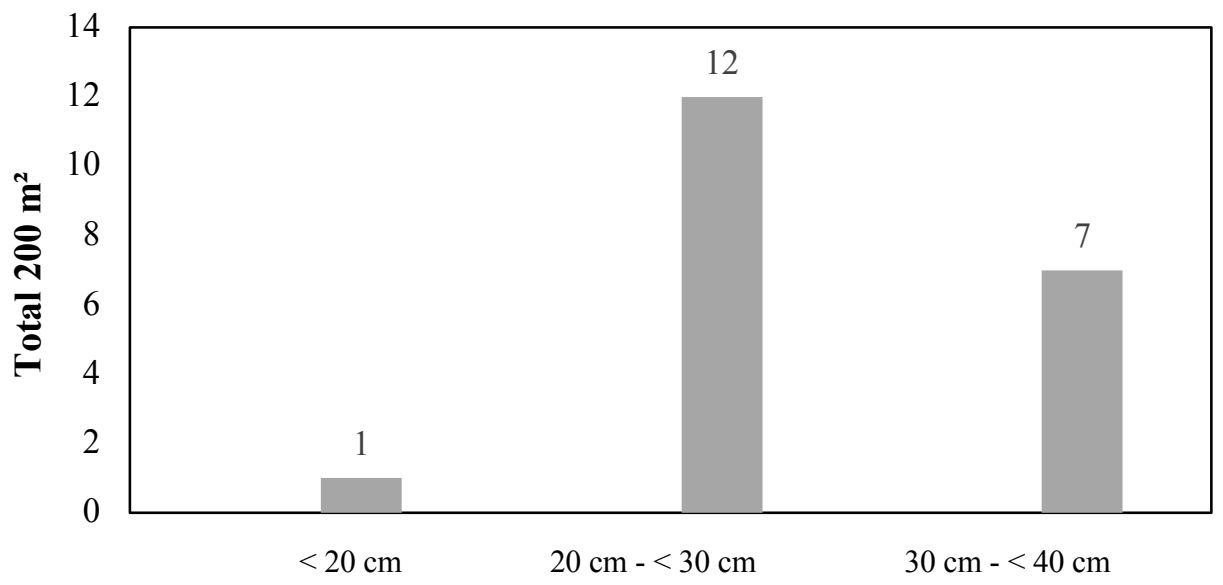

Diameter class

Fig. 5. The diameter class distribution of $R$. apiculata.

Based on the diameter class in Fig. 5 and Fig. 6, the observation locations were included in a less normal regeneration condition because the number of individuals in the diameter class $<20$ $\mathrm{cm}$ in $R$. apiculata and $R$. mucronata were fewer than those in the $20-30 \mathrm{~cm}$ diameter class. However, the diameter class of $20-30 \mathrm{~cm}$ to $>30 \mathrm{~cm}$ showed normal regeneration, characterized by fewer individuals as the diameter class increased. It might be due to the logging activities in the 
classes, which were smaller than $20 \mathrm{~cm}$ in diameter for firewood purposes because, at the observation site, the mangrove logging activities were found to be used as firewood. It was reported that the demands of the coastal communities influenced the activities and the damage to mangrove forests in TTU Regency to fulfill their firewood needs (Ledheng et al. 2012).

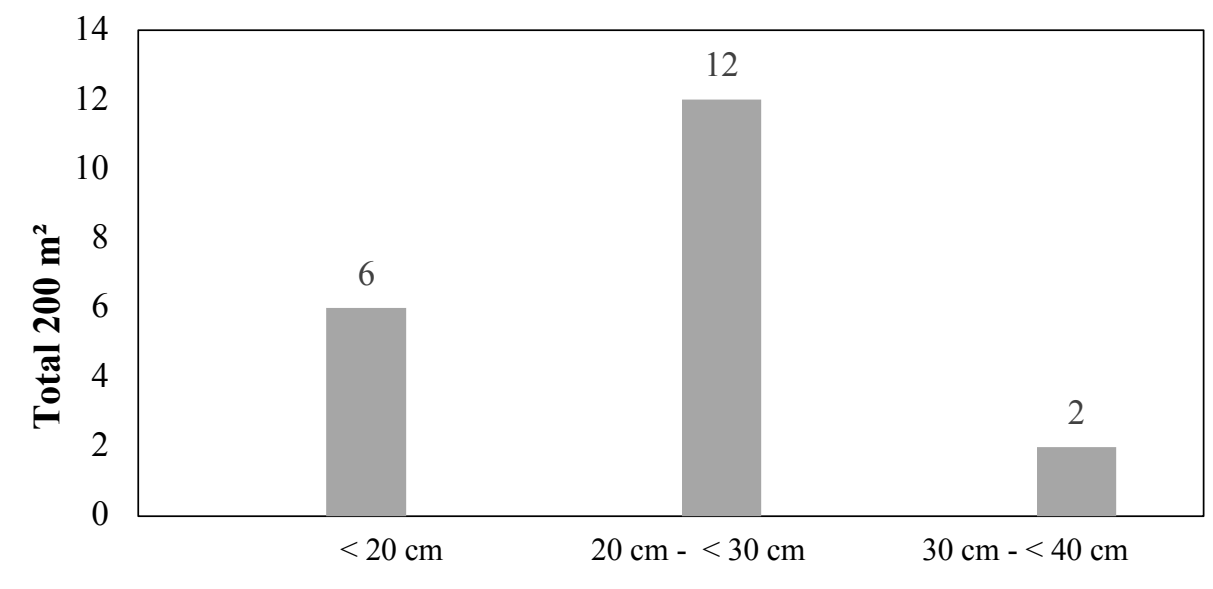

Diameter class

Fig. 6. The diameter class distribution of $R$. mucronata.

\subsection{Necromass}

The calculation of necromass began with measuring the diameter and height of dead trees. The result showed that the dead tree of $R$. apiculata with a height of $3.64 \mathrm{~m}$ and a diameter of $35.72 \mathrm{~cm}$ had a necromass of $3.06 \mathrm{~kg}$ and could store and absorb carbon as much as $1.53 \mathrm{~kg}$ and $5.62 \mathrm{~kg}$, respectively. The result of this observation was greater than the necromass of the dead trees, with a height of $4.16 \mathrm{~m}$ and a diameter of $28.72 \mathrm{~cm}$. It was found that a total of $2.26 \mathrm{~kg}$ could store and absorb carbon of $1.13 \mathrm{~kg}$ and $4.13 \mathrm{~kg}$, respectively. This observation data showed that the difference in the height of dead trees did not affect the necromass content but was influenced by the diameter. The observation of the dead tree in $R$. mucronata with a height of $6.63 \mathrm{~m}$ and a diameter of $27.05 \mathrm{~cm}$ had a necromass of $3.20 \mathrm{~kg}$ and could store and absorb carbon of $1.60 \mathrm{~kg}$ and $5.87 \mathrm{~kg}$, respectively. This necromass value was higher than the necromass in the dead trees with other heights and diameters. The necromass values are presented in Table 4.

Table 4. Necromass at the observation site

\begin{tabular}{cccccc}
\hline Location & Height $(\mathbf{c m})$ & Dbh $(\mathbf{c m})$ & Biomass $(\mathbf{k g})$ & Carbon content $(\mathbf{k g})$ & $\mathbf{C O}_{2}$ uptake (kg) \\
\hline 1 & 3.64 & 35.72 & 3.06 & 1.53 & 5.62 \\
& 4.52 & 28.29 & 2.39 & 1.19 & 4.38 \\
& 4.16 & 28.72 & 2.26 & 1.13 & 4.15 \\
Total & & & $7.71 \mathrm{a}$ & $3.85 \mathrm{a}$ & $14.14 \mathrm{a}$ \\
\hline 2 & 6.63 & 27.05 & 3.20 & 1.60 & 5.87 \\
& 5.21 & 25.20 & 2.18 & 1.09 & 4.00 \\
& 4.50 & 23.45 & 1.63 & 0.82 & 2.99 \\
Total & & & $7.01 \mathrm{a}$ & $3.51 \mathrm{a}$ & $12.87 \mathrm{a}$ \\
\hline
\end{tabular}

Note: Numbers followed by the same notation do not differ according to the t-test at significant level $\alpha=0.05$. 
The dead trees of $R$. apiculata stored and absorbed carbon of $3.85 \mathrm{~kg}$ and $14.14 \mathrm{~kg}$, respectively (Table 4). The dead tree of $R$. mucronata stored and absorbed carbon by $3.51 \mathrm{~kg}$ and $12.87 \mathrm{~kg}$, respectively. It illustrates that the larger the diameter, the higher the necromass content in the dead trees. Therefore, the dead trees with large diameters store and absorb more carbon (Ariani et al. 2016). However, the result of the t-test did not show any difference in the necromass, carbon content, and $\mathrm{CO}_{2}$ uptake. It is suspected that the dead tree samples found in the observation site generally had a similar shape, so the value of the form factor also influences. The necromass of the dead trees at each location was analyzed using a correction value of 0.60 (National Standardization Agency, 2011). The result of the t-test is presented in Table 5.

Table 5. The t-test result of dead tree carbon storage

\begin{tabular}{lc}
\hline \multicolumn{1}{c}{ Parameter } & Sig. (2-tailed) \\
\hline Necromass & 0.68 \\
Carbon content & 0.69 \\
$\mathrm{CO}_{2}$ uptake & 0.68 \\
\hline
\end{tabular}

The carbon content and $\mathrm{CO}_{2}$ uptake of the dead trees as a whole were $7.36 \mathrm{~kg}$ and $26.90 \mathrm{~kg}$, which were lower than that observed in the mangrove area of Tarjun Village, South Kalimantan (Ariani et al. 2016), showing the carbon content and $\mathrm{CO}_{2}$ uptake of $22.20 \mathrm{~kg}$ and $81.4 \mathrm{~kg}$. Mughofar et al. (2018) reported the presence of $R$. mucronata in the coastline zone (the area directly facing the sea) and the presence of $R$. apiculata in the middle zone (an area located behind the coastline zone). Therefore, the presence of the dead trees from zoning is also influenced by the tidal movements of seawater. The number of different dead trees in this study is thought to be due to the influence of waves hitting the mangroves in the shoreline zone. It has caused the age of the mangroves in that zone to be younger than the zone behind the coastline resulting in the mangroves in that area cannot adapt to the extreme tidal conditions so that the dead stands were found in the coastline zone. Table 4 shows that the diameter of trees killed by $R$. mucronata was smaller than that of $R$. apiculata. It has been demonstrated that $R$. mucronata stands were younger and had less wave resistance, making them easy to break and die. Meanwhile, the location of $R$. apiculata stands was close to the settlements, which caused the trees' stems and branches to be cut down more often for the home industry purposes. At the observation site, it was found to make the table salt by a group of people using wood fuel.

\subsection{Above-Ground Biomass}

The above-ground biomass (AGB ) is the total observed biomass above the ground level. This study observed the tree trunk biomass and the dead tree necromass. The results of AGB are presented in Table 6.

Table 6. Above-ground biomass $(\mathrm{Mg} / \mathrm{ha})$

\begin{tabular}{lcccccc}
\hline \multirow{2}{*}{ Species } & \multicolumn{2}{c}{ Biomass } & \multicolumn{2}{c}{ Carbon content } & \multicolumn{2}{c}{$\mathbf{C O}_{2}$ uptake } \\
\cline { 2 - 7 } & Tree & Necromass & Tree & Necromass & Tree & Necromass \\
\hline R. apiculata & 39.42 & 0.04 & 19.71 & 0.02 & 72.33 & 0.07 \\
R. mucronata & 37.79 & 0.03 & 18.90 & 0.02 & 69.35 & 0.06 \\
\hline \multicolumn{1}{c}{ Total } & \multicolumn{2}{c}{77.28} & \multicolumn{2}{c}{38.64} & \multicolumn{2}{c}{141.81} \\
\hline
\end{tabular}


The AGB value reached $77.21 \mathrm{Mg} / \mathrm{ha}$ and could store and absorb carbon of $38.61 \mathrm{Mg} / \mathrm{ha}$ and $141.68 \mathrm{Mg} / \mathrm{ha}$, respectively. This observation result was greater than the AGB value of the wildlife reserve, Karang Gading, North Sumatra, which was $9.05 \mathrm{Mg} /$ ha with a carbon content of 4.25 $\mathrm{Mg} / \mathrm{ha}$ (Barus and Kuswanda 2016) in an area of 6,000 $\mathrm{m}^{2}$. According to Golden Agri-Resources (2012), the forest with an estimated carbon of approximately $192 \mathrm{Mg} / \mathrm{ha}$ is categorized into the high-density forests; the medium density forests has an estimated carbon of $166 \mathrm{Mg} / \mathrm{ha}$, while the low-density forest has an estimated carbon of less than or equal to $107 \mathrm{Mg} / \mathrm{ha}$.

\section{Conclusions}

The results of the t-test on diameter, biomass, carbon content, and the $\mathrm{CO}_{2}$ uptake of $R$. apiculata and $R$. mucronata in Tuamese Village were not significantly different. It shows that $R$. apiculata and $R$. mucronata in the sapling to tree growth strata have the same potential to store and absorb the carbon. The total biomass was $77.21 \mathrm{Mg} / \mathrm{ha}$, which could store and absorb 36.61 $\mathrm{Mg} / \mathrm{ha}$ and $141.68 \mathrm{Mg} / \mathrm{ha}$, respectively. The result of this study has provided an overview of the biomass and carbon potential of the dominant species in the mangrove area in Tuamese village. Therefore, it can be used to measure the achievement of the economic value of environmental services in actualizing the success of the conservation.

\section{References}

Amira, S. 2008. Pendugaan Biomassa Jenis Rhizophora apiculata Bl. di Hutan Mangrove Batu Ampar Kabupaten Kubu Raya, Kalimantan Barat. Skripsi. Institut Pertanian Bogor. Bogor

Ariani, E., Ruslan, M., Kurnain, A., and Kissinger. 2016. Analisis Potensi Simpanan Karbon Karbon Hutan Mangrove di Area PT. Indocement Tunggal Prakasa, Tbk P12 Tarjun. EnviroScienteae 12(3): 312-329. DOI: 10.20527/es.v12i3.2456

Barus, S. P., and Kuswanda, W. 2016. Nilai ekonomi Jasa Lingkungan Hutan Mangrove di Suaka Margasatwa Karang Gading, Sumareta Utara. Jurnal Penelitian Hutan dan Konservasi Alam 13(1): 29-41. DOI: 10.20886/jphka.2016.13.1.29-41

Dewiyanti, I., Martunis, M., and Agustina, S. 2019. Estimation of Mangrove Biomass and Carbon Absorption of Rhizophora apiculata and Rhizophora mucronata in Banda Aceh, Aceh Province, Banda Aceh, Aceh Province, Indonesia. IOP Conference Series: Earth and Environmental Science 348: 012119. DOI: 10.1088/1755-1315/348/1/012119

Dharmawan, I. W. S. 2010. Pendugaan Biomasa Karbon di Atas Tanah pada Tegakan Rhizophora mucronata di Ciasem Purwakarta. Jurnal Ilmu Pertanian Indonesia 15(1): 50-56.

Golden Agri-Resources. 2012. Hutan Berstok Karbon Tinggi: Laporan Penelitian. Golden AgriResources. Jakarta, Indonesia.

Hairiah, K., and Rahayu, S. 2007. Pengukuran 'Karbon Tersimpan' di Berbagai Macam Penggunaan Lahan. World Agroforestry Centre - ICRAF. Bogor.

Heriyanto, N. M., and Subiandono, E. 2012. Komposisi dan Struktur Tegakan, Biomassa, dan Potensi Kandungan Karbon Hutan Mangrove di Taman Nasional Alas Purwo. Jurnal Penelitian Hutan dan Konservasi Alam 9(1): 23-32. DOI: 10.20886/jphka.2012.9.1.023-032 Herpinawati, Dahlan, Z., and Sarno. 2010. Tingkat Pertumbuhan dan Biomassa Bibit Rhizophora apiculata Perairan Delta Upang Banyuasin Sumatera Selatan. Maspari Journal 1(1): 59-62. DOI: 10.36706/maspari.v1i1.1116

Irawan, B., Muadz, M., and Rosadi, A. 2013. Karakterisasi dan Kekerabatan Tumbuhan 
Mangrove Rhizophoraceae Berdasarkan Morfologi, Anatomi dan Struktur Luar Serbuk Sari. Prosiding Seminar Nasional Sains dan Teknologi Nuklir PTNBR - BATAN. 289-297.

Jumiati, E. 2008. Pertumbuhan Rhizophora mucronata dan R. apiculata di Kawasan Berlantung. Jurnal Manajemen Hutan Tropika 14(3): 104-110.

Ledheng, L., Ardhana, I., and Sundra, I. K. 2012. Komposisi dan Struktur Vegetasi Mangrove di Pantai Tanjung Bastian Kabupaten Timor Tengah Utara Provinsi Nusa Tenggara Timur. Ecotrophic: Jurnal Ilmu Lingkungan 4(2): 80-85.

Ledheng, L., Naisumu, Y. G., and Binsasi, R. 2020. Kajian Biomassa dan Cadangan Carbon pada Hutan Mangrove Pantai Utara Kabupaten Timor Tengah Utara Provinsi Nusa Tenggara Timur. Prosiding Seminar Nasional SMIPT 3(1): 217-229.

Manafe, G., Kaho, M. R., and Risamasu, F. 2016. Estimasi Biomassa Permukaan dan Stok Karbon pada Tegakan Pohon Avicennia marina dan Rhizophora mucronata di Perairan Pesisir Oebelo Kabupaten Kupang. Jurnal Bumi Lestari 16(2): 163-173. DOI: 10.24843/blje.2016.v16.i02.p09

Mughofar, A., Masykuri, M., and Setyono, P. 2018. Zonasi dan Komposisi Vegetasi Hutan Mangrove Pantai Cengkrong Desa Karanggandu Kabupaten Trenggalek Provinsi Jawa Timur. Jurnal Pengelolaan Sumberdaya Alam dan Lingkungan 8(1): 77-85. DOI: 10.29244/jps1.8.1.77-85

Mustika, D. I., Rusdiana, O., and Sukendro, A. 2014. Pertumbuhan Bakau Minyak (Rhizophora apiculata) di Persemaian Mangrove Desa Muara Teluk Naga, Tangerang, Banten. Bonorowo Wetlands 4(2): 108-116. DOI: 10.13057/bonorowo/w040204

National Standardization Agency. 2011. Standard Nasional Indonesia SNI 7724: Jakarta, Indonesia: Penulis

Nurruhwati, I., and Purwita, S. D. 2018. Blue Carbon Content of Mangrove Vegetation in Subang district. Conference Series: Earth and Environmental Science 137: 012065. DOI: 10.1088/1755-1315/137/1/012065

Qiu, Y. W., Yu, K. F., Zhang, G., and Wang, W. X. 2011. Accumulation and Partitioning of Seven Trace Metals in Mangroves and Sediment Cores from Three Estuarine Wetlands of Hainan Island, China. Journal of Hazardous Materials 190(1-3): 631-638. DOI: 10.1016/j.jhazmat.2011.03.091

Regional Government of North Central Timor. 2016. Rencana Pembangunan Jangka Menengah Daerah Tahun 2016 - 2021. Government of North Central Timor. Kefamenanu, Indonesia.

Rahim, S., Baderan, D. K., and Hamidun, M. S. 2018. Keanekaragaman Spesies Biomassa dan Stok Karbon pada Hutan Mangrove Torosiaje Kabupaten Pohuwato Provinsi Gorontalo. Jurnal Pro-Life 5(3): 650-665. DOI: 10.33541/jpvol6Iss2pp102

Weyerhaeuser, H., and Tennigkeit, T. 2000. Forest Inventory and Monitoring Manual. HBSICRAF-CMU: 1-30. 